\title{
LITHOLOGY INTERPRETATION BASED ON WELL LOG DATA ANALYSIS IN “JS” FIELD
}

\author{
Tri Wulan Sari' ${ }^{1}$, Sujito ${ }^{2}$ \\ ${ }^{1}$ Reservoir Geophysics Program, Departement of Physics, FMIPA Universitas Indonesia, 16424 \\ Indonesia \\ ${ }^{2}$ Major of Physics, FMIPA Universitas Negeri Malang, Malang, 65145, Indonesia \\ e-mail : triwulansari3006@ gmail.com ${ }^{\text {; }}$ sujito.fmipa@um.ac.id ${ }^{2}$
}

\begin{abstract}
Reservoir lithology types in a prospect zone of hydrocarbon can be known through well log data analysis, both qualitatively and quantitatively. Lithology interpretation based on qualitatively well log data analysis, has been successfully carried out by K-1 and K-3 well log data on JS Field, West Natuna basin, Riau Islands. Main focus of the research is types of lithology indicated by response the petrophysical well data log of Lower-Middle Miocene Arang Formation. Arang Formation was deposited immediately on top Barat formation and depositional environment in this formation is transitional marine - marine. Petrophysics log shows well data are log gamma ray, resistivity, neutron porosity, density, and sonic. The limitation of study are on four types lithology, they are coal, sand, sally sand, and shale. Lithology on well K-1 dominate by shale, there is thin intersection between sand and coal. The well of K-1 have sand thickest around six meter. While on well K-3 Petrophysics log data shows thin intersection between coal, sand, shaly sand, and dominated by shale. The thickest Sand have thickness 29 meter, and thicker than on K-1 well. The result in this study, the formation dominated by types of lithology "shale".
\end{abstract}

Keywords : Lithology; Well Log; Qualitatively

\section{INTRODUCTION}

Identification of hydrocarbon prospect zone can be done by analyzing drilling well $\log$ data, both qualitatively and quantitatively. To continuously measure formation properties with electrically powered instruments to infer properties and make decisions about drilling and production operations.

The record of the measurements, typically a long strip of paper, is also called a log (Schlumberger, 2019). According to Bates and Jackson (1985, on Inakhairina, 2012). interpreting lithology to be 2 , first Lithology is a description of rocks in outcrops based on their characteristics, such as: color, mineral composition and grain size. Synonym with Petrografi, and second Lithology is the physical characteristic of rocks.
In the research of Irawan and Utama (2016), lithology types were generally composed of sandstones, claystone, sandy sand, shaly sand, limestone and bedrock. In this study, qualitative analysis of well log data was carried out by analyzing the characteristics of log data to determine the type of lithology below the surface on "JS" field.

\section{METHODS}

Well Data in the studies get from PT Pertalahan Arnebatara Natuna, TAC Pertamina. The well data consist of deviation survey data and $\log$ ascii standard or las (Syesar, 2016). The Petrophysics log shows well data are log gamma ray, resistivity, neutron porosity, density, and sonic. (Figure 1, Log header on each well) (Sari, et al, 2016). 
Focus study is the type of lithology indicated bythe response of K- 1 and K-3 well $\log$ data in JS Field, West Natuna Basin, Riau Islands. The main focus in Lower-Middle Miocene Arang Formation was deposited immediately on top Barat formation and depositional environment in this formation is transitional marine marine (Figure 2, Stratigraphic column of the West Natuna Basin).

Interpretation of lithology by Analysis of qualitatively well log data through two steps (Anonim, 2015). First step is import well $\log$ data to software geophysics Petrel. You can learn many ways to import data into Petrel. Second step is analysis of data result in Petrel based on well $\log$ data response indicated by petrophysical log shown different characteristic of lithology. Researcher take 4 characteristic of lithology types.

In the Table 1, if the type is coal, gamma ray $\log$ shows 0 until $32.5 \mathrm{API}$, resistivity more than $5000 \mathrm{ohm} . \mathrm{m}$, and the highest NPHI, the smallest RHOB (Sari, 2016). If the sand gamma ray log shows 32.5 until 60 API, resistivity between 100 until 5000 ohm.m, and the highest NPHI, small RHOB (Sari, 2016). If shaly sand, you get gamma ray log shows value between 60 until 70 API, resistivity between 30 until $100 \mathrm{ohm} . \mathrm{m}$, and the highest NPHI, small RHOB (Sari, 2016). If lithology types show shale, so gamma ray log have value more than 70 API, resistivity between 3 until $30 \mathrm{ohm} . \mathrm{m}$, and the smallest NPHI, small RHOB (Sari, 2016). The depth unit on this study is mTVDSS, calculated sea depth does not include deflection, be measured from mean sea level.

\section{RESULTS AND DISCUSSION}

In the Figure 3, The lithological type of rock in K-1 Well. Lithology types shows on depth 1054.4 until 1206.7 mTVDSS. There is thin layer of coal on depth 1057 - 1058, 1142 - 1144, 1160 - 1162, 1177 $-1179 m$ TVDSS. Next thin layer of sand on depth 1044 - 1047, 1083-1084, 1086

$-1088,1133-1135,1144-1147,1161$

$-1162,1178-1180,1183-1189,1194$

-1197 mTVDSS.

The thin layer of shaly sand also shows very much on depth range. The well of K-1 have coal thickest around 2 meter on $\quad 1177-1179 m T V D S S$, sand six meter on between 1183 - 1189 $m T V D S S$, shaly sand 0.5 meter on between 1147,5 - 1148,5 mTVDSS and shale 45 meter on between 1088 - 1133 $m$ TVDSS (Abdul and Sari, 2017).The lithology K- 1 well is dominated by shale, there are thin intersection sand, coal and shaly sand.

In the Figure 4, The lithological type of rock in K-3 Well. Lithology types shows on depth 985.3 until 1422.9 mTVDSS. There is thin layer coal on depth 1030 1035,1100 - 1105, 1135 - 1140, 1140 $1145 m$ TVDSS and thin intersection at the depth below. Next thin layer sand on depth 1065 - 1075, 1105 - 1120, 1195 $1200 m T V D S S$. The thin layer of shaly sand also shows very much on depth range. The well of K-3 have thickest sand has a thickness of 29 meters found at a depth between 1145 - 1175 mTVDSS. The type of log GR response contained in the sand is blocky with deposition environment is channel (Sari, 2016). The well is dominated by shale, there are thin intersection sand, coal and shaly sand (Sari and Saputro, 2017)

\section{CONCLUSION}

The K-1 and K-3 well is dominated by shale, there are thin intersection sand, coal and shaly sand. The thickest Sand from K3 well is 29 meter, and thicker than on K1 well is 6 meter. 


\section{ACKNOWLEDGEMENT}

1. Aryo Nugroho Joyo Suyono as sponsor and supporter in this research.

2. Rossi Andi Saputro as mentor and data provider at PT. Pertalahan Arnebatara Natuna, TAC Pertamina.

\section{REFERENCES}

Abdul, H., and T.W Sari, (2017, July). Delineating stratigraphic trap reservoir using RGB color blending of spectral decomposition method: Case study in the West Natuna Basin. AIP Conference Proceedings 1862, 030182. Universitas Indonesia, Indonesia.

Anonim. 2015. Analisa Kualitatif Wireline Log. https://geohazard009.wordpress.co $\mathrm{m} / 2015 / 02 / 25 /$ analisa-kualitatifwireline-log/. 30 July 2019.

Inakhairina. (2012). Geologi Dasar. https://www.scribd.com/doc/28367 8 938/Geologi-Dasar. 30 July 2019.

Irawan, D, Utama, W, and Parafianto, T. (2009). Analisis Data Well Log (Porositas, Saturasi Air, dan Permeabilitas) untuk menentukan Zona Hidrokarbon, Studi Kasus: Lapangan "ITS" Daerah Cekungan Jawa Barat Utara. Institut Teknologi Sepuluh Nopember, 1-7.

Sari, T,W. (2016). Pemetaan Distribusi Reservoir Jebakan Stratigrafi pada Lapangan TS menggunakan Metode
Penggabungan Red Green Blue (RGB) dari Hasil Dekomposisi Spektral (pp. 19-29). Universitas Indonesia : FMIPA. Unpublished Literature.

Sari, T,W. Supriyanto, dkk. (2016). Distribusi Reservoir Lapisan Tipis Batupasir menggunakan Metode Dekomposisi Spektral Fast Fourier Transform (FFT) pada Lapangan "Suki". Seminar Nasional Jurusan Fisika. 3-4.

Sari, T.W, and R. A. Saputro, (2017, September). Successful Delineation of Thin Channel Deposit Reservoir by Applying RGB Blending of Spectral Decomposition Method: Case Study in SA Field, West Natuna Basin. International Conference by HAGI (2017), Malang, Indonesia.

Schlumberger Limited. (2019). Well Log.https://www.glossary.oilfield.slb .co m/en/Terms/w/well_log.aspx. 31 July 2019.

Syesar, M. N. F. (2016). Pemodelan Sekatan Sesar Pada Lapangan MSFN, Sub-Cekungan Palembangm, Cekungan Sumatera Selatan (pp. 52- 63). Universitas Gadjah Mada. 


\section{Appendix}

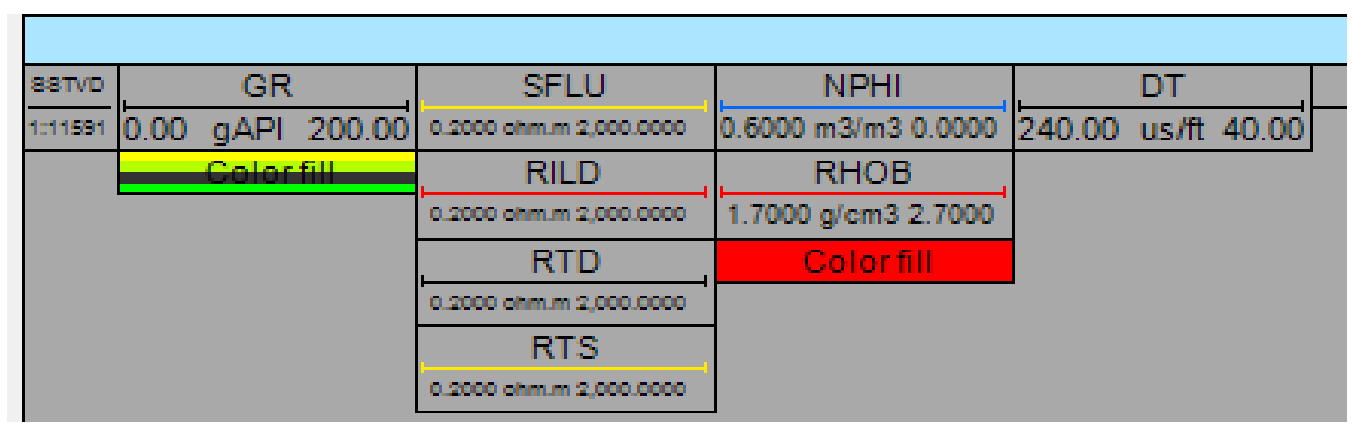

Figure 1. Log header on each well [4]

Table 1. Characteristic of lithology types based on value petrophysics log

\begin{tabular}{|c|c|c|c|}
\hline Lithology Types & $G R(A P I)$ & $\begin{array}{l}\text { Resistivity } \\
\text { (ohm.m) }\end{array}$ & $N P H I \& R H O B$ \\
\hline Coal & $0-32.5$ & $>5000$ & NPHI $>>$, RHOB $<<$, \\
\hline Sand & $32.5-60$ & $100-5000$ & NPHI >>, RHOB < \\
\hline $\begin{array}{l}\text { Shaly } \\
\text { sand }\end{array}$ & $60-70$ & $30-100$ & NPHI >>, RHOB < \\
\hline Shale & $>70$ & $3-30$ & NPHI >, RHOB < \\
\hline
\end{tabular}

(Source : in Thesis Sari. T. W (2016) [7]) 


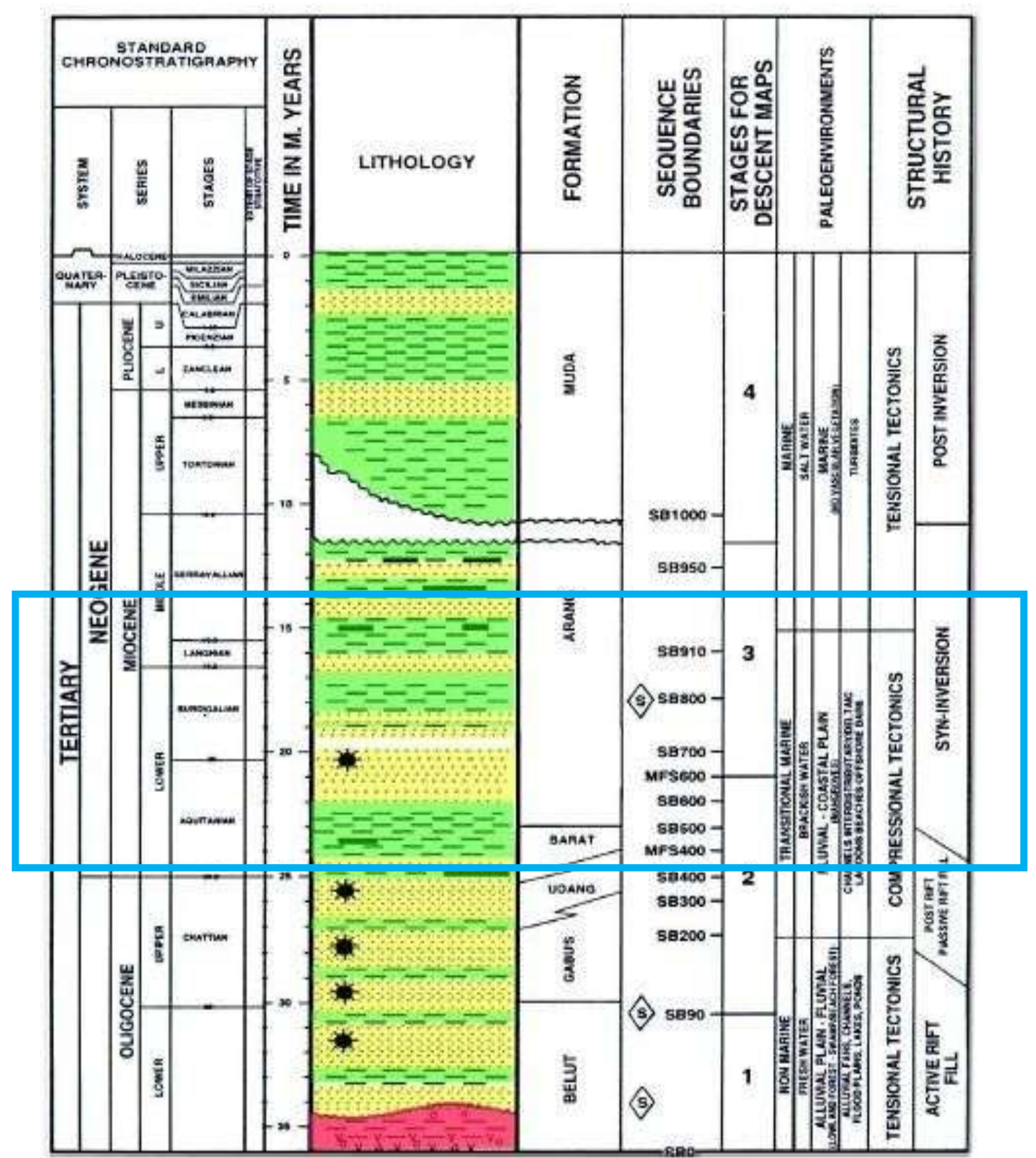

Figure 2. Stratigraphic column of the West Natuna Basin [4] 


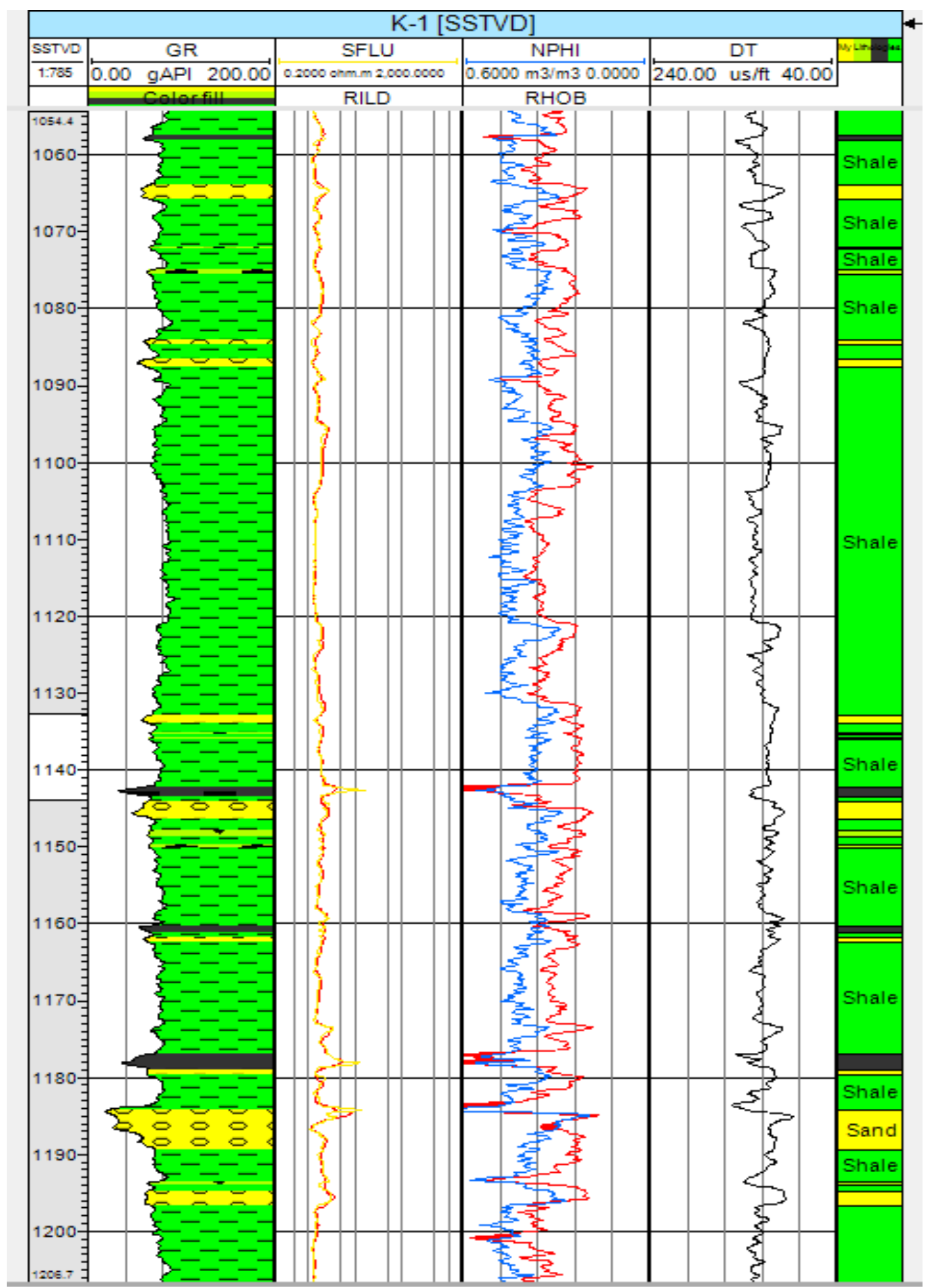

Figure 3. The lithological type of rock in K-1 Well 
Applied Research on Civil Engineering and Environment (ARCEE) VOL. 01 No. 01, August 2019

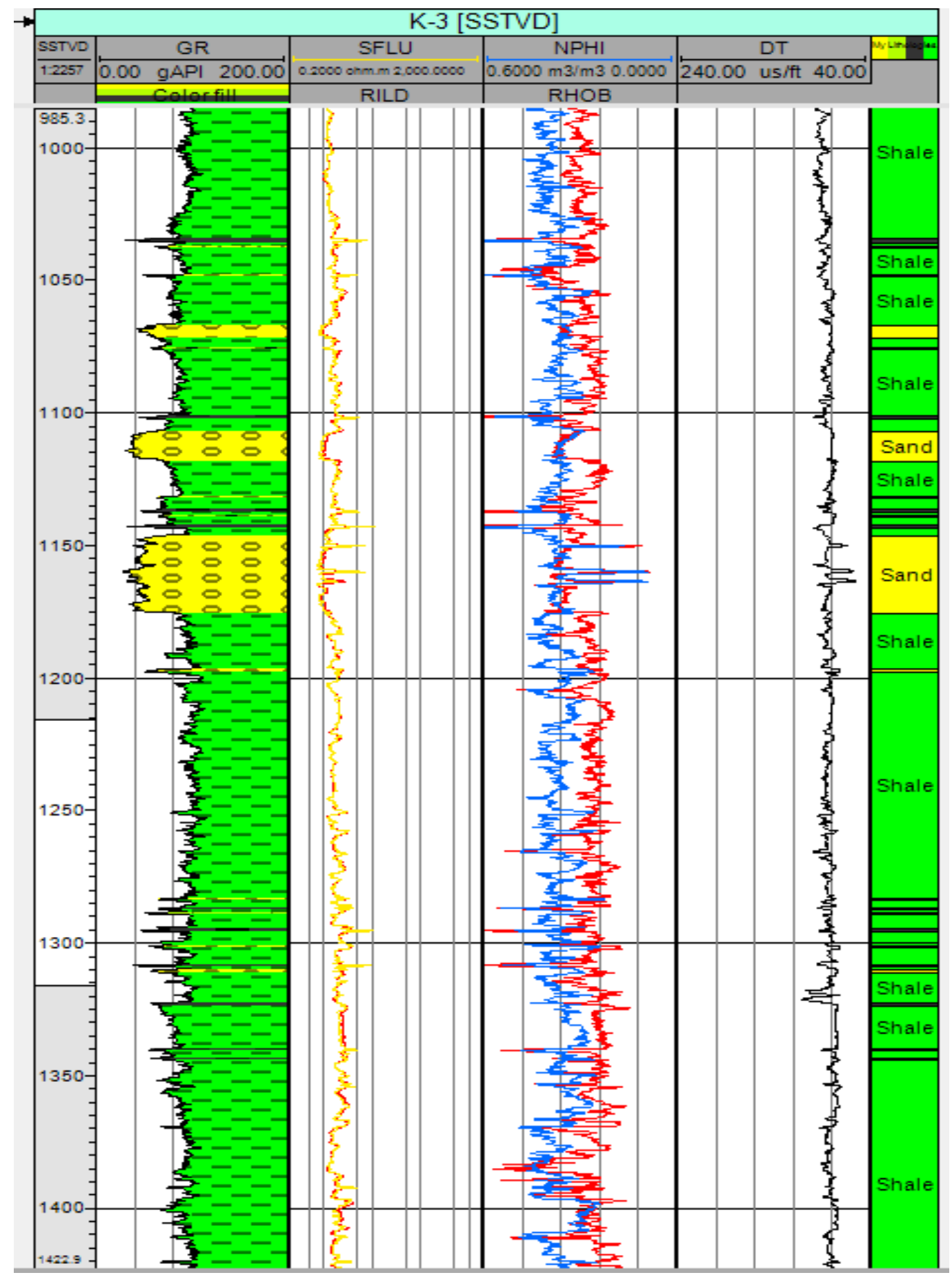

Figure 4. The lithological type of rock in K-3 Well 